\title{
Mycobacterium hiberniae sp. nov.
}

\author{
J. KAZDA ${ }^{1 *}$ R. COONEY, ${ }^{2}$ M. MONAGHAN,${ }^{2}$ P. J. QUINN,${ }^{2}$ E. STACKEBRANDT, ${ }^{3}$ \\ M. DORSCH,${ }^{3}$ M. DAFFÉ, ${ }^{4}$ K. MÜLLER,${ }^{5}$ B. R. COOK,${ }^{2} \dagger$ AND Z. S. TARNOK ${ }^{1}$ \\ Research Institute for Experimental Biology and Medicine, Parkallee 1-40, D-2061 Borstel, ${ }^{1}$ and Department \\ of Botany, University of Kiel, Kiel, ${ }^{5}$ Germany; Faculty of Veterinary Medicine, University College Dublin, \\ Ballsbridge, Dublin, Ireland ${ }^{2}$; Department of Microbiology, Centre for Bacterial Diversity and \\ Identification, University of Queensland, St. Lucia, Queensland, Australia ${ }^{3}$; and \\ Department III, Laboratoire de Pharmacologie et de Toxicologie Fondamentales, \\ Centre National de la Recherche Scientifique, Toulouse Cedex, France ${ }^{4}$
}

\begin{abstract}
Strains of a new type of slowly growing scotochromogenic, rose-pink-pigmented mycobacterium were isolated repeatedly from sphagnum vegetation, true moss, and soil in Ireland. These strains grew at 22, 31, and $37^{\circ} \mathrm{C}$ but not at $45^{\circ} \mathrm{C}$ and possessed acid phosphatase and arylsulfatase activities. They reduced nitrate, tolerated $0.1 \% \mathrm{NaNO}_{2}$, did not split amides, and were resistant to most of the antituberculous drugs tested, except ethambutol. They did not form acid from glucose and mannose. Their internal phenetic similarity was $97.08 \% \pm 2.07 \%$. The whole mycolate pattern confirmed the homogeneity of the taxa sharing similar mycolate types with several other mycobacterial species. However, on the basis of the nature of the major pyrolysis esters, the taxon appeared unique. The phylogenetic analysis based on evolutionary distance values revealed that the strains belong to a new species of slowly growing mycobacteria. The DNA-DNA hybridization values confirmed that these strains differ significantly from Mycobacterium nonchromogenicum, M. terrae, M. triviale, and $M$. thermoresistibile. The strains produced a unique rose-pink pigment and were nonpathogenic for mice, guinea pigs, and rabbits, but they provoked a nonspecific hypersensitivity reaction to bovine tuberculin in guinea pigs and cattle. Hence, they are considered a member of a new species of nonpathogenic slowly growing mycobacteria, for which the name Mycobacterium hiberniae is proposed. Strain Hi 11 is the type strain, a culture of which has been deposited in the American Type Culture Collection as strain ATCC 49874.
\end{abstract}

During 1990 and 1991, 13 strains with homogenous properties belonging to the genus Mycobacterium were isolated on culture media for mycobacteria from true moss, sphagnum vegetation, and soil collected in the counties Clare and Donegal in Ireland. These strains were nonpathogenic, produced cross-sensitivity to bovine tuberculin, and are regarded as a source of nonspecific reactions in cattle in some regions of Ireland. The properties of these strains indicate that they belong to a new species of slowly growing mycobacteria. In this paper, the results of a taxonomic and molecular genetic study are described.

\section{MATERIALS AND METHODS}

Bacterial strains. The origins of 13 strains of mycobacteria that have not been previously described (referred to below as Hi strains) were sphagnum vegetation (Sphagnum subnitens), true moss (Acrocladium cuspidatum, Amblystegium varium, Atrichum undulatum, and Ctenidium molluscum), and soil, collected in 1990 and 1991 in the counties Clare and Donegal, Ireland. The type strain $\mathrm{Hi} 11^{\mathrm{T}}$ was found in Ctenidium molluscum vegetation.

Methods. Colony morphology and the ability to grow at various temperatures $\left(22,31,37,42\right.$, and $\left.45^{\circ} \mathrm{C}\right)$ were determined after 4 weeks of incubation on Löwenstein-Jensen slants and Middlebrook 7H10 agar inoculated with $10^{-2} \mathrm{mg}$ of cells per cultivation test. Pigment production in the dark and photoactivity after 6 weeks of incubation were determined as previously described $(13,22)$. The following tests were also performed as described previously: nitrate reduction and catalase activity $(6,22)$; Tween hydrolysis $(22)$; acid

\footnotetext{
* Corresponding author.

† Permanent address: Tauranga, New Zealand.
}

phosphatase production (15); arylsulfatase activity after 3 and 10 days (18); production of acetamidase, benzamidase, urease, isonicotinamidase, nicotinamidase, pyrazinamidase, succinamidase, allantoinase, and malonamidase (5); and resistance to 1 and $5 \mu \mathrm{g}$ of ethambutol per $\mathrm{ml}, 1$ and $10 \mu \mathrm{g}$ of isoniazid per $\mathrm{ml}, 20 \mu \mathrm{g}$ of rifampin per $\mathrm{ml}, 5 \mu \mathrm{g}$ of streptomycin per $\mathrm{ml}$, and 10 and $40 \mu \mathrm{g}$ of ethionamide per $\mathrm{ml}(34)$. In addition, resistance to $0.1 \% \mathrm{NaNO}_{2}$ (33) and to $0.2 \%$ picric acid (32) were also tested. Acid production from glucose and mannose was tested in agar medium during 6 weeks of incubation $(13,22)$.

The lipid analyses were carried out by using cells separated from Löwenstein-Jensen slants. Cells were saponified in 5\% (wt/vol) $\mathrm{KOH}$ in 2-methoxyethanol (Methylcellosolve) containing $12 \%$ (vol/vol) $\mathrm{H}_{2} \mathrm{O}$ at $110^{\circ} \mathrm{C}$ for $4 \mathrm{~h}$ to ensure complete hydrolysis of sterically hindered ester groups. After acidification with $\mathrm{H}_{2} \mathrm{SO}_{4}$, the solution was partitioned between diethyl ether and water. The ether phase was washed five times with distilled water and dried. Free fatty acids in extracts were esterified for $15 \mathrm{~min}$ at room temperature by using freshly prepared diethyl ether solution of diazomethane. The solution was then dried under nitrogen, and the lipids were redissolved in diethyl ether and analyzed by thin-layer chromatography. The mycolate patterns were determined as previously described (9). The fatty acids, methyl esters, and alcohols were determined by gas chromatography with a Perkin-Elmer model $8310 \mathrm{~B}$ gas chromatograph fitted with a 1-m-high column packed with $3 \%$ OV-1. Nitrogen was used as the carrier gas. To determine the composition of the chain in position 2 of the mycolates, pyrolytic conditions were used, with the injection temperature raised from 300 to $400^{\circ} \mathrm{C}$. Cultures of strain $\mathrm{Hi} 11^{\mathrm{T}}$ and $\mathrm{Hi} 2$ that were 4 weeks old were tested for pathogenicity. For each strain, three rabbits were inoculated intravenously 
with $10 \mathrm{mg}$ (wet weight) of bacteria, five NMRI white mice were injected intravenously with $1 \mathrm{mg}$ of bacteria, and three white guinea pigs were injected subcutaneously with $10 \mathrm{mg}$ of bacteria. After 14 weeks, the animals were necropsied (21).

Phylogenetic analysis. The $16 \mathrm{~S}$ rRNA gene of strain $\mathrm{Hi} 11^{\mathrm{T}}$ ( $T$, type strain) was amplified by the polymerase chain reaction technique and sequenced as described previously (11).

The sequence was aligned manually to the $16 \mathrm{~S}$ rRNA data base of more than 70 mycobacterial strains $(17,25)$. For the phylogenetic analysis, only those positions that were unambiguously present in each of the sequences were included. The stretch that was analyzed comprised 1,419 nucleotide positions present in each of the sequences, i.e., positions 50 to 72,99 to 199,214 to 451 , and 479 to 1376 (according to the method of Weisburg et al. [35]).

Pairwise evolutionary distances (expressed as estimated changes per 100 nucleotides) were computed from the percent similarities by the correction of Jukes and Cantor (14). A phylogenetic tree was constructed from the distance matrix by the algorithm of De Soete (10). The reproducibility of the branching nodes was examined by the neighborjoining bootstrapping programs PDFIND and NJBOOT (kindly provided by T. S. Whittam, Institute of Molecular Evolution and Genetics, Pennsylvania State University). One thousand trees were generated and examined. Sequence alignment and data analysis were done by using a Sun Sparc Workstation IPC.

In addition, a quantitative evaluation of the DNA-DNA hybridization technique with sulfonated DNA (Sulfo-DNA; Biozym, Hameln, Germany) was included to monitor the difference between the $\mathrm{Hi} 11^{\mathrm{T}}$ strain and $M$. triviale, $M$. terrae, $M$. nonchromogenicum, and $M$. thermoresistibile (31).

Numerical analyses. On the basis of a comparison of 32 properties, the level of internal similarity of the $13 \mathrm{Hi}$ strains was determined (28). A total of 33 properties of $M$. terrae, $M$. nonchromogenicum, $M$. thermoresistibile, and $M$. triviale and 32 properties of 17 other species of slowly growing mycobacteria were determined and compared with the properties of strain $\mathrm{Hi} 11^{\mathrm{T}}$. All the data obtained were converted to the simple binary (i.e., 1 or 0 ) for analysis; both negative and positive matches were used (28).

Nucleotide sequence accession number. The partial $16 \mathrm{~S}$ rRNA sequence of strain $\mathrm{Hi} 11^{\mathrm{T}}$, consisting of 1,419 nucleotides, has been deposited in GenBank under accession number X67096.

\section{RESULTS AND DISCUSSION}

The cells of the $13 \mathrm{Hi}$ strains grown on Löwenstein-Jensen medium and on Middlebrook 7H10 agar were beaded rods ( 0.9 by 1.2 to $1.5 \mu \mathrm{m}$ ), often polymorphic, gram positive, and acid-alcohol fast, and very often formed clumps but not cords. Spores, capsules, true branching, and aerial hyphae were not observed. On Löwenstein-Jensen medium, the strains were eugonic in the first phase of growth, becoming dysgonic later, and produced rose-pink-pigmented colonies, which assumed a rough, dry appearance after 8 weeks when incubated at temperatures between 22 and $37^{\circ} \mathrm{C}$. At $37^{\circ} \mathrm{C}$, growth was observed after 20 days; at $31^{\circ} \mathrm{C}$, growth was observed after 25 days; at $22^{\circ} \mathrm{C}$, growth was observed after 4 weeks. No growth occurred at 42 or $45^{\circ} \mathrm{C}$. Smooth, compact, rose-pink colonies, 1 to $1.5 \mathrm{~mm}$ in diameter, with entire margins developed on Middlebrook 7H10 agar from dilute
TABLE 1. Characteristics of 13 Hi strains

\begin{tabular}{|c|c|}
\hline Characteristic & $\begin{array}{l}\% \text { of strains giving } \\
\text { positive reaction }\end{array}$ \\
\hline Pigment production in the dark ... & 100 \\
\hline Photoactivity after 4 weeks ................................. & 0 \\
\hline \multicolumn{2}{|l|}{ Growth after 4 weeks at: } \\
\hline 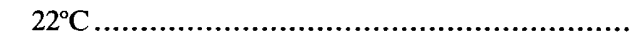 & 100 \\
\hline $31^{\circ} \mathrm{C} \ldots$ & 100 \\
\hline $37^{\circ} \mathrm{C} \ldots$ & 100 \\
\hline $45^{\circ} \mathrm{C} .$. & 0 \\
\hline \multicolumn{2}{|l|}{ Enzymatic activity: } \\
\hline Acid phosphatase $\left(37^{\circ} \mathrm{C}, 20 \mathrm{~h}\right)$ & 100 \\
\hline Arylsulfatase (10 days) ............. & 100 \\
\hline Nitrate reductase $\left(37^{\circ} \mathrm{C}, 22 \mathrm{~h}\right) \ldots \ldots \ldots \ldots \ldots \ldots \ldots \ldots$ & 100 \\
\hline Tween hydrolysis (10 days) .... & $46^{a}$ \\
\hline 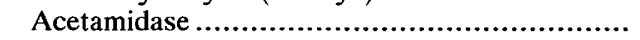 & 0 \\
\hline Benzamidase .................... & 0 \\
\hline Urease & 0 \\
\hline Isonicotinamidase & 0 \\
\hline Nicotinamidase & 0 \\
\hline Pyrazinamidase & 0 \\
\hline Allantoinase ................. & 0 \\
\hline Succinamidase ............... & 0 \\
\hline \multicolumn{2}{|l|}{ Tolerance to: } \\
\hline $\mathrm{NaNO}_{2}(0.1 \%) \ldots \ldots \ldots$ & 100 \\
\hline Picric acid $(0.2 \%) \ldots \ldots$ & 0 \\
\hline \multicolumn{2}{|l|}{ Acid production from: } \\
\hline 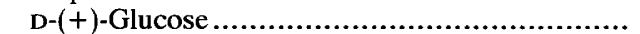 & 0 \\
\hline 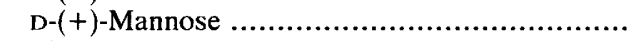 & 0 \\
\hline \multicolumn{2}{|l|}{ Resistance to: } \\
\hline \multicolumn{2}{|l|}{ Ethambutol } \\
\hline $5 \mu \mathrm{g} / \mathrm{ml}$ & 0 \\
\hline $1 \mathrm{gg} / \mathrm{ml}$ & $23^{b}$ \\
\hline \multicolumn{2}{|l|}{ Isonicotinic acid } \\
\hline $10 \mu \mathrm{g} / \mathrm{ml} \ldots \ldots \ldots \ldots \ldots$ & 100 \\
\hline $1 \mu \mathrm{g} / \mathrm{ml}$ & 100 \\
\hline 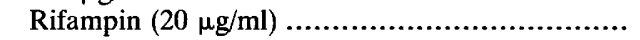 & 100 \\
\hline Streptomycin $(5 \mu \mathrm{g} / \mathrm{ml}) \ldots \ldots \ldots \ldots \ldots \ldots \ldots \ldots \ldots \ldots$ & 100 \\
\hline \multicolumn{2}{|l|}{ Ethionamide } \\
\hline $10 \mu \mathrm{g} / \mathrm{ml}$. & 100 \\
\hline 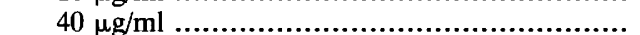 & 100 \\
\hline
\end{tabular}

${ }^{a}$ Strains $\mathrm{Hi}$ 3, Hi 6, Hi 8, Hi 10, Hi 11, and $\mathrm{Hi} 13$ were positive.

${ }^{b}$ Strains Hi 1, Hi 2, and Hi 10 were positive.

inocula at $37^{\circ} \mathrm{C}$. A total of 32 properties of the Hi strains are shown in Table 1 . These strains constitute a homogeneous group, with a level of internal similarity of $97.08 \% \pm 2.07 \%$.

A comparison of the properties of strain $\mathrm{Hi} 11^{\mathrm{T}}$ with the properties of 22 species of slowly growing mycobacteria showed marked differences from other mycobacterial species (Table 2). The whole-cell mycolate pattern of the $\mathrm{Hi}$ strains (Table 3) confirmed the homogeneity of the new taxon, sharing similar mycolate types with several other mycobacterial species, notably the $M$. avium-M. intracellulare complex $(9,23)$. However, on the basis of the nature of the major pyrolysis esters (doco- and tetracosanoate), the taxon appears unique among the group of species that synthesize the same type of mycolates $(9,20)$.

The 16S rRNA sequence of strain $\mathrm{Hi} 11^{\mathrm{T}}$ is unique among mycobacteria, exhibiting the highest degree of variation in the variable regions V1, positions 64 to 104 (26), and V3, positions 437 to 497 (24), compared with more than 70 mycobacterial sequences. A phylogenetic analysis (Fig. 1), based on evolutionary distance values (Table 4), revealed that strain $\mathrm{Hi} 11^{\mathrm{T}}$ fell into the confines of slowly growing mycobacteria. This position is supported by the presence of a long helix between positions 451 and 482 (part of region 
TABLE 2. Similarity values between strain $\mathrm{Hi} 11^{\mathrm{T}}$ and strains of 22 species of slowly growing mycobacteria

\begin{tabular}{|c|c|}
\hline Organism and strain & $\%$ Similarity \\
\hline M. terrae TMC $1450 .$. & 84.8 \\
\hline M. gordonae TMC 1324 . & 81.8 \\
\hline M. nonchromogenicum TMC 1481 . & 78.8 \\
\hline M. triviale TMC $1453 \ldots \ldots \ldots \ldots \ldots$ & 78.8 \\
\hline M. asiaticum ATCC $25276 \ldots$. & 78.1 \\
\hline M. intracellulare ATCC $23434 .$. & 75.0 \\
\hline M. szulgai NCTC $10831 \ldots . . . \ldots . . . .$. & 75.0 \\
\hline M. scrofulaceum TMC $1323 .$. & 71.8 \\
\hline M. flavescens TMC 1541 . & 71.8 \\
\hline M. marinum ATCC $927 .$. & 71.8 \\
\hline M. avium TMC $724 \ldots . .$. & 68.8 \\
\hline M. gastri ATCC 15754 . & 68.8 \\
\hline M. ulcerans ATCC 19423 & 68.8 \\
\hline M. xenopi ATCC $19250 \ldots$. & 68.8 \\
\hline M. shimoidei ATCC 27952. & 68.8 \\
\hline M. bovis ATCC $19210 \ldots$ & 65.6 \\
\hline M. kansasii TMC $1204 \ldots$ & 65.6 \\
\hline M. cookii ATCC $49103 .$. & 65.6 \\
\hline M. simiae ATCC $25275 .$. & 62.5 \\
\hline 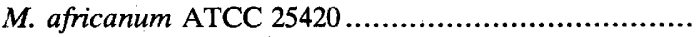 & 59.4 \\
\hline 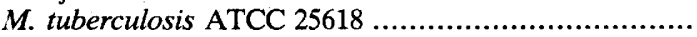 & 56.3 \\
\hline M. malmoense ATCC $29571 \ldots$ & 53.1 \\
\hline
\end{tabular}

V3) of the $16 \mathrm{~S}$ rRNA, which is a significant signature of all slowly growing members of the genus $(25,26,29,30)$. In particular, strain $\mathrm{Hi} 11^{\mathrm{T}}$ exhibits a close relationship to a subcluster of slowly growing mycobacteria consisting of $M$. terrae ATCC $15755^{\mathrm{T}}$ and $M$. nonchromogenicum ATCC $19530^{\mathrm{T}}(25)$. This clustering is supported by the presence of a $U$ residue at position 1274 , an additional base pair in region $\mathrm{V} 3$, and a 9-base loop in region V8 (the last two unique features are also found in $M$. cookii [16]). High bootstrap values of $95 \%$ support the membership of $M$. hiberniae in the $M$. terrae-M. nonchromogenicum cluster, as well as the clustering of most of the other slowly growing mycobacteria. Interestingly, the branching point of the $M$. terrae cluster (42\%), and even more so of $M$. cookii within the radiation of the slowly growing mycobacteria, is of little statistic significance $(10 \%)$.

Over the complete stretch of 1,419 nucleotides, the degree

TABLE 3. Mycolate types, major pyrolysis esters, and fatty acid and alcohol composition in $13 \mathrm{Hi}$ strains

\begin{tabular}{|c|c|}
\hline Composition pattern & $\begin{array}{l}\text { Response of all } \\
\text { Hi strains }\end{array}$ \\
\hline \multicolumn{2}{|l|}{ Mycolate type $^{a}$} \\
\hline I.................. & + \\
\hline .................... & - \\
\hline ........................ & - \\
\hline IV $\ldots \ldots \ldots \ldots \ldots \ldots \ldots \ldots$ & + \\
\hline 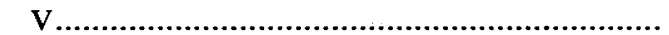 & - \\
\hline 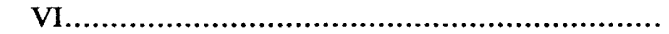 & + \\
\hline \multicolumn{2}{|l|}{ 2-OH } \\
\hline C-18 ....................... & + \\
\hline 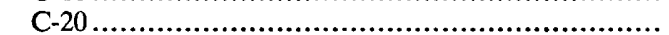 & + \\
\hline C-22 & - \\
\hline \multicolumn{2}{|l|}{ Major pyrolysis ester } \\
\hline C $-22 \ldots \ldots \ldots \ldots \ldots \ldots \ldots \ldots \ldots$ & + \\
\hline $\mathrm{C}-24 \ldots \ldots \ldots \ldots \ldots \ldots$ & + \\
\hline 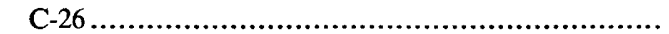 & - \\
\hline
\end{tabular}

${ }^{a}$ The mycolate types have been described previously (9).

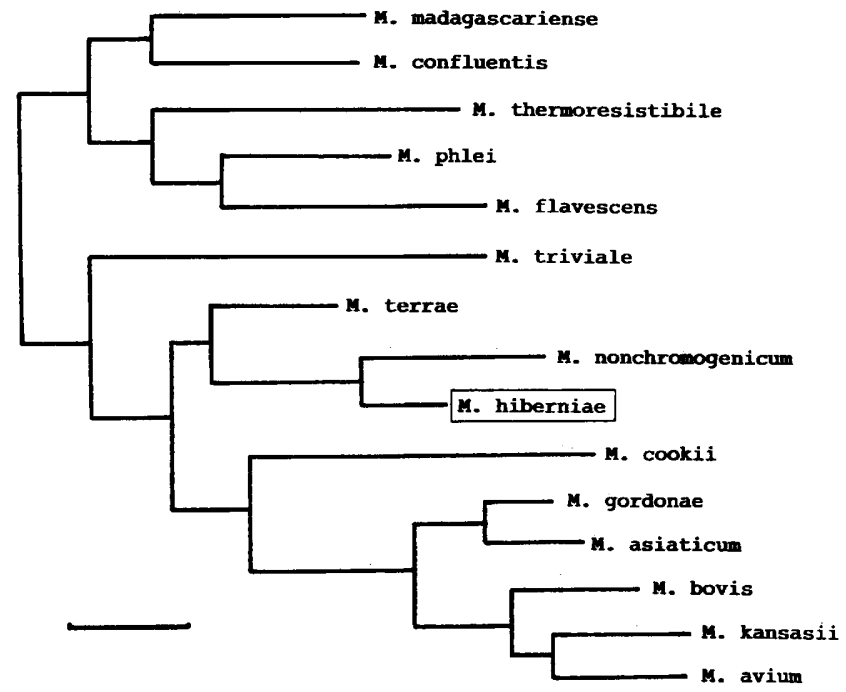

FIG. 1. Phylogenetic position of $M$. hiberniae ATCC $49874^{\mathrm{T}}$ (strain $\mathrm{Hi}$ 11) within the radiation of slowly growing mycobacteria. A more detailed branching pattern of slowly growing and fastgrowing mycobacteria has been published in reference 25 . The horizontal components of the branch lengths are proportional to evolutionary distances. The bar indicates $1 \%$ nucleotide differences.

of similarity between strain $\mathrm{Hi} 11^{\mathrm{T}}$ and $M$. nonchromogenicum is substantial $(98.7 \%)$.

Similarly high values have been found between strains of closely related species, e.g., Fibrobacter spp. (1), Lactococcus lactis (7), Streptococcus parasanguis (36), and $M$. intracellulare $(4,12,30)$, and also between closely related species, such as certain slowly growing mycobacteria $(25,27$, 29) (Fig. 1), Streptococcus spp. (3), Fusobacterium spp. (19), Listeria spp. (8), and Enterococcus casseliflavus and Enterococcus gallinarum (37). Consequently, it has been stressed that it is not possible to draw definite conclusions about species differentiation on the basis of 16S rRNA sequences alone $(1,2,12)$. The decision of whether to describe a species depends upon the availability of other data, such as DNA hybridization (31) and/or phenotypic differences to neighboring taxa. In the present case, the decision to describe a new species was based on the presence of a unique rose-pink pigment, sensitization to bovine tuberculin, and certain other properties listed below.

The Hi strains are mycobacteria with very limited enzymatic activity. All strains possess acid phosphatase, nitrate reductase, and catalase. Arylsulfatase production was delayed, becoming positive after 10 days of incubation. No amidase activity was found. These strains tolerated $0.1 \%$ $\mathrm{NaNO}_{2}$ but were susceptible to $0.2 \%$ picric acid. They did not produce acid from glucose and mannose. All strains were susceptible to $5 \mu \mathrm{g}$ of ethambutol but resistant to isonicotinic acid, rifampin, streptomycin, and ethionamide in the concentrations tested.

Furthermore, they did not utilize any of the compounds tested. Their optimal growth temperature of $37^{\circ} \mathrm{C}$ is very unusual for environmental strains originating from a moderate climate. The rose-pink pigmentation is unique within the genus Mycobacterium. The strains were not pathogenic for experimental animals, but they provoked a cross-reaction to bovine tuberculin in guinea pigs and cattle. The strains have a mycolate pattern similar to that of the $M$. avium- $M$. intracellulare complex. However, all $\mathrm{Hi}$ strains released by 
TABLE 4. Evolutionary distances for the $16 \mathrm{~S}$ rRNAs of $M$. hiberniae ATCC $49874^{\mathrm{T}}$ and various representatives of slowly growing and fast-growing mycobacteria ${ }^{a}$

\begin{tabular}{|c|c|c|c|c|c|c|c|c|c|c|c|c|c|}
\hline Organism & 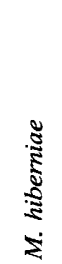 & 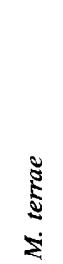 & 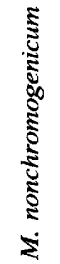 & $\begin{array}{l}3 \\
8 \\
8 \\
8 \\
\Sigma\end{array}$ & 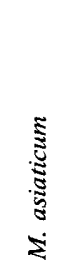 & 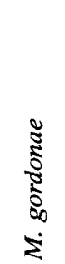 & 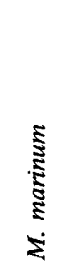 & 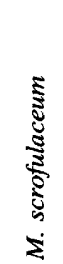 & 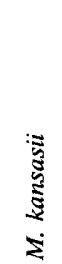 & 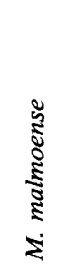 & 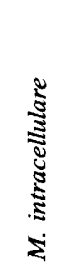 & 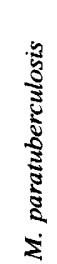 & $\begin{array}{l}3 \\
8 \\
z \\
z\end{array}$ \\
\hline M. terrae & 1.9 & & & & & & & & & & & & \\
\hline M. nonchromogenicum & 1.0 & 1.6 & & & & & & & & & & & \\
\hline M. cookii & 2.7 & 2.4 & 2.4 & & & & & & & & & & \\
\hline M. asiaticum & 3.5 & 2.1 & 3.5 & 2.7 & & & & & & & & & \\
\hline M. gordonae & 3.7 & 2.7 & 3.3 & 2.8 & 1.4 & & & & & & & & \\
\hline M. marinum & 3.1 & 2.4 & 3.0 & 2.6 & 1.6 & 2.0 & & & & & & & \\
\hline M. scrofulaceum & 3.7 & 3.4 & 3.5 & 3.0 & 2.1 & 1.9 & 1.1 & & & & & & \\
\hline M. kansasii & 3.8 & 3.5 & 3.7 & 3.3 & 2.1 & 2.0 & 1.2 & 0.4 & & & & & \\
\hline M. malmoense & 3.8 & 3.5 & 3.5 & 3.2 & 2.1 & 2.0 & 1.3 & 0.6 & 0.8 & & & & \\
\hline M. intracellulare & 3.7 & 3.5 & 3.5 & 3.4 & 2.4 & 2.2 & 1.4 & 0.6 & 1.0 & 0.8 & & & \\
\hline M. paratuberculosis & 3.5 & 3.5 & 3.3 & 3.3 & 2.1 & 2.0 & 1.2 & 0.8 & 1.0 & 0.8 & 0.5 & & \\
\hline M. bovis & 3.0 & 2.4 & 2.9 & 2.6 & 1.6 & 2.0 & 0.3 & 1.2 & 1.2 & 1.2 & 1.5 & 1.2 & \\
\hline M. triviale & 3.1 & 3.0 & 2.7 & 2.9 & 3.8 & 3.5 & 3.7 & 3.6 & 3.9 & 4.0 & 4.2 & 3.9 & 3.6 \\
\hline Fast-growing mycobacteria ${ }^{b}$ & \multicolumn{12}{|c|}{$1.7-4.6$} & \\
\hline
\end{tabular}

the pyrolysis of their mycolates, C-22 and C-24 fatty esters, whereas the $M$. avium- $M$. intracellulare complex releases only C-24 fatty esters. The nature of the pyrolysis esters is regarded as specific and stable for a given species (9).

The DNA-DNA hybridization confirmed the homogeneity of the $13 \mathrm{Hi}$ strains and demonstrated the differences from $M$. nonchromogenicum, $M$. terrae, and $M$. thermoresistibile (Table 5).

Taxonomic description of Mycobacterium hiberniae sp. nov. Mycobacterium hiberniae (hi.ber' ni.ae. L. gen. n. hiberniae, of Hibernia, the Latin name for Ireland, the source of these strains). The description of $M$. hiberniae presented below is based on a study of 13 strains which shared the characteristics shown in Table 1 . Cells are acid-alcohol fast, polymorphic, beaded rods ( 0.9 by 1.2 to $1.5 \mu \mathrm{m})$ which very often form clumps but not cords. Spores, capsules, true branching, and aerial hyphae do not occur. Colonies on Löwenstein-Jensen and Middlebrook 7H10 agar are smooth and glistening with rose-pink pigmentation but become rough and dry later. The colonies with the unique pigment production are 1 to $1.5 \mathrm{~mm}$ in diameter; optimum growth occurs at $37^{\circ} \mathrm{C}$. They grow at 22 and $31^{\circ} \mathrm{C}$ but not at 42 or $45^{\circ} \mathrm{C}$. Biochemical characteristics are shown in Table 1 . The strains are mycobacteria with limited enzymatic activity.

TABLE 5. Comparison of DNA-DNA hybridization values for $\mathrm{Hi}$ $11^{\mathrm{T}}$ and type strains of $M$. terrae, $M$. nonchromogenicum, $M$. thermoresistibile, and $M$. triviale

\begin{tabular}{|c|c|}
\hline Organism & $\begin{array}{l}\text { \% DNA similarity } \\
\text { with } \mathrm{Hi} 11^{\mathrm{T}}\end{array}$ \\
\hline M. terrae.. & 14.29 \\
\hline M. nonchromogenicum. & 28.57 \\
\hline 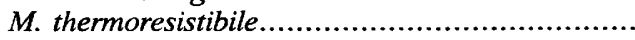 & 28.57 \\
\hline 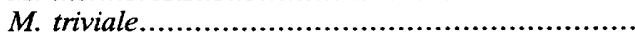 & 28.75 \\
\hline
\end{tabular}

They possess acid phosphatase, nitrate reductase, and arylsulfatase. For all strains, amidase activities and acid production from glucose and mannose are negative. These organisms tolerate $0.1 \% \mathrm{NaNO}_{2}$ but not $0.2 \%$ picric acid. The strains are resistant to antituberculous drugs, except to $5 \mu \mathrm{g}$ of ethambutol (Table 1). The strains have a mycolate pattern similar to that of the $M$. avium- $M$. intracellulare complex, but they release by pyrolysis their mycolate $\mathrm{C}-22$ and $\mathrm{C}-24$ fatty esters, a unique characteristic for $M$. hiberniae.

The strains which were tested are not pathogenic for rabbits, guinea pigs, or mice. They provoke a nonspecific skin hypersensitivity reaction to bovine tuberculin. The type strain of $M$. hiberniae is Hi 11 . A culture of this strain has been deposited in the American Type Culture Collection as strain ATCC 49874. Strains of $M$. hiberniae have been isolated from true moss, sphagnum, and soil in Ireland.

Characteristics which differentiate $M$. hiberniae from other related mycobacteria. $M$. hiberniae can be differentiated from $M$. gordonae by its positive nitrate reductase activity, by its failure to produce acid from glucose, by its production of a rose-pink pigment, and by marked differences in the whole mycolate pattern and the $16 \mathrm{~S}$ rRNA sequences.

$M$. hiberniae is easily differentiated from $M$. terrae by its rose-pink pigment formation and its positive arylsulfatase activity. There are a number of differences in the 16S rRNA sequences, major pyrolysis esters, and DNA-DNA hybridization values.

$M$. hiberniae can be differentiated from $M$. triviale by its production of a rose-pink pigment and its resistance to isonicotinic acid and rifampin. There are also marked differences in the major pyrolysis esters, 16S rRNA sequences, and DNA-DNA hybridization values.

$M$. hiberniae can be differentiated from $M$. nonchromogenicum by its slow growth on media, by its production of a rose-pink pigment, by its failure to split nicotinamide and pyrazinamide, and by its failure to produce acid from glu- 
cose. There are marked differences in the major pyrolysis esters and DNA-DNA hybridization values.

Generally, $M$. hiberniae differs from all other mycobacterial species described thus far by its unusual rose-pink pigmentation, which is unique in the genus Mycobacterium.

\section{ACKNOWLEDGMENT}

This project was a part of the International Cooperation in Science and Technology between Germany and Ireland and financially supported by grants, IRL-BIO-2 and 0319425A from the Federal Ministry for Research and Technology, Bonn, Germany, and EOLAS, Dublin, Ireland, and from the NH \& MRC, Canberra, Australia.

We thank H. K. Bianchi, GKSS, Forschungszentrum Geesthacht, Germany, and T. Moran, EOLAS, Dublin, Ireland, for excellent coordination of this project and Hilde Hahn, Cornelia Rodde, Elke Link and Werner Mohr for skillful technical assistance.

\section{REFERENCES}

1. Amiann, R. I., C. Lin, R. Key, L. Montgomery, and D. A. Stahl. 1992. Diversity among Fibrobacter isolates: towards a phylogenetic classification. Syst. Appl. Microbiol. 15:23-31.

2. Ash, C., A. E. Farrow, M. Dorsch, E. Stackebrandt, and M. D. Collins. 1991. Comparative analysis of Bacillus anthracis, Bacillus cereus, and related species on the basis of reverse transcriptase sequencing of $16 \mathrm{~S}$ rRNA. Int. J. Syst. Bacteriol. 41:343-346.

3. Bentley, R. W., J. A. Leigh, and M. D. Collins. 1991. Intrageneric structure of Streptococcus based on comparative analysis of small-subunit rRNA sequences. Int. J. Syst. Bacteriol. 41: $487-494$.

4. Böddinghaus, B., J. Wolters, W. Heikens, and E. C. Böttger. 1990. Phylogenetic analysis and identification of different serovars of Mycobacterium intracellulare at the molecular level. FEMS Microbiol. Lett. 70:197-204.

5. Bönicke, R. 1961. Die Bedeutung der Acylamidasen für die Identifizierung und Differenzierung der verschiedenen Arten der Gattung Mycobacterium. Jahresber. Borstel 5:7-87.

6. Bönicke, R. 1962. Identification of mycobacteria by biochemical methods. Bull. Int. Union Tuberc. 32:13-86.

7. Collins, M. D., C. Ash, J. A. E. Farrow, S. Wallbanks, and A. M. Williams. 1989. 16S ribosomal ribonucleic acid sequence analysis of lactococci and related taxa. Description of Vagococcus fluvialis gen. nov., sp. nov. J. Appl. Bacteriol. 67:453-460.

8. Collins, M. D., S. Wallbanks, D. J. Lane, J. Shah, R. Nietupski, J. Smida, M. Dorsch, and E. Stackebrandt. 1991. Phylogenetic analysis of the genus Listeria based on reverse transcriptase sequencing of 16S rRNA. Int. J. Syst. Bacteriol. 41:240-246.

9. Daffé, M., M. A. Laneélle, C. Asselineau, V. Lévy-Frébault, and H. David. 1983. Intéret taxonomique des acides gras des mycobactéries: proposition d'une méthode d'analyse. Ann. Inst. Pasteur Microbiol. 134B:241-256.

10. De Soete, G. 1983. A least squares algorithm for fitting additive trees to proximity data. Psychometrika 48:621-626.

11. Dorsch, M., and E. Stackebrandt. 1992. Some modifications in the procedure of direct sequencing of PCR amplified $16 \mathrm{~S}$ rDNA. J. Microbiol. Methods, 6:271-279.

12. Fox, F. E., J. W. Wisotzkey, and P. Jurtshuk, Jr. 1992. How close is close: $16 \mathrm{~S}$ rRNA sequence identity may not be sufficient to guarantee species identity. Int. J. Syst. Bacteriol. 42:166-170.

13. Gordon, R. E., and M. M. Smith. 1953. Rapidly growing, acid-fast bacteria. I. Species descriptions of Mycobacterium phlei Lehmann and Neumann and Mycobacterium smegmatis (Trevisan) Lehmann and Neumann. J. Bacteriol. 66:41-48.

14. Jukes, T. H., and C. R. Cantor. 1969. Evolution of protein molecules, p. 21-132. In N. H. Munro (ed.), Mammalian protein metabolism. Academic Press, New York.

15. Käppler, W. 1965. Zur Differenzierung von Mykobakterien mit dem Phosphatase-Test. Beitr. Klin. Tuberk. Spezif. Tuberk. Forsch. 130:223-226.

16. Kazda, J., H.-J. Müller, E. Stackebrandt, M. Daffe, K. Müller, and C. Pitulle. 1992. Mycobacterium madagascariense sp. nov. Int. J. Syst. Bacteriol. 42:524-528.

17. Kirschner, P., A. Teske, K.-H. Schröder, R. M. Kroppenstedt, J. Wolters, and E. C. Böttger. 1992. Mycobacterium confluentis sp. nov. Int. J. Syst. Bacteriol. 42:257-262.

18. Kubica, G. P., and A. L. Ridgon. 1961. The arylsulfatase activity of acid-fast bacilli. III. Preliminary investigation of rapidly growing acid-fast bacilli. Am. Rev. Respir. Dis. 83:737-740.

19. Lawson, P. A., S. E. Gharbia, H. N. Shah, D. R. Clark, and M. D. Collins. 1991. Intrageneric relationships of members of the genus Fusobacterium as determined by reverse transcriptase sequencing of small-subunit rRNA. Int. J. Syst. Bacteriol. 41:347-354.

20. Luquin, M., V. Ausina, F. López Calahorra, F. Belda, M. García Barceló, C. Celma, and G. Prats. 1991. Evaluation of practical chromatographic procedures for identification of clinical isolates of mycobacteria. J. Clin. Microbiol. 29:120-130.

21. Meissner, G. 1959. Untersuchungen an atypischen Mykobakterien. II. Vergleichende tierexperimentelle Untersuchungen zur Frage ihrer Pathogenität und Virulenz. Beitr. Klin. Tuberk. Spezif. Tuberk. Forsch. 121:365-380.

22. Meissner, G., K.-H. Schröder, G. E. Amadis, W. Anz, S. Chaparas, H. B. W. Engel, P. A. Jenkins, W. Käppler, H. H. Kleeberg, E. Kubala, M. Kubin, D. Lauterbach, A. Lind, M. Magnusson, Z. Mikova, S. R. Pattyn, W. B. Schaefer, J. L. Stanford, M. Tsukamura, L. G. Wayne, I. Willers, and E. Wolinsky. 1974. A cooperative numerical analysis of nonscotoand nonphotochromogenic slowly growing mycobacteria. J. Gen. Microbiol. 83:207-235.

23. Minnikin, D. E., S. M. Minnikin, J. H. Parlett, M. Goodfellow, and M. Magnusson. 1984. Mycolic acid patterns of some species of Mycobacterium. Arch. Microbiol. 139:225-231.

24. Neefs, I. M., Y. Van de Peer, L. Hendriks, and P. De Wachter. 1990. Complication of small ribosomal subunit RNA sequences. Nucleic Acids Res. 18:2237-2317.

25. Pitulle, C., M. Dorsch, J. Kazda, J. Wolter, and E. Stackebrandt. 1992 . The phylogeny of rapidly growing members of the genus Mycobacterium. Int. J. Syst. Bacteriol, 42:337-343.

26. Rogall, T., T. Flohr, and E. Böttger. 1990. Differentiation of Mycobacterium species by direct sequencing of amplified DNA. J. Gen. Microbiol. 136:1915-1920.

27. Rogall, T., J. Wolters, T. Flohr, and E. C. Böttger. 1990. Towards a phylogeny and definition of species at the molecular level within the genus Mycobacterium. Int. J. Syst. Bacteriol. 40:323-330.

28. Sokal, R. R., and P. H. A. Sneath. 1963. Principles of numerical taxonomy. W. H. Freeman \& Co., San Francisco.

29. Stackebrandt, E., and J. Smida. 1988. The phylogeny of the genus Mycobacterium as determined by $16 \mathrm{~S}$ rRNA sequences, and development of DNA-probes, p. 244-250. In Y. Okami, T. Beppu, and H. Ogawara (ed.), Biology of actinomycetes '88. Japan Scientific Societies Press, Tokyo.

30. Stahl, D. A., and J. W. Urbance. 1990. The division between fast- and slow-growing species corresponds to the natural relationships among the mycobacteria. J. Bacteriol. 172:116-124.

31. Tarnok, Z. S., I. Tarnok, and A. Tarnok. 1991. Bestimmung von DNA-DNA Homologien mit Hilfe sulfonierter DNA und 4-Methylumfelliferil-Phosphat. Bioforum 14:180-184.

32. Tsukamura, M. 1965. Differentiation of mycobacteria by picric acid tolerance. Am. Rev. Respir. Dis. 92:491-492.

33. Tsukamura, M., and S. Tsukamura. 1968. Differentiation of mycobacteria by susceptibility to nitrite and propylene glycol. Am. Rev. Respir. Dis. 98:505-506.

34. Wayne, L. G., R. C. Good, M. I. Krichevsky, R. E. Beam, Z. Blacklock, S. D. Chaparas, D. Dawson, S. Froman, W. Gross, J. Hawkins, P. A. Jenkins, I. Juhlin, W. Käppler, H. H. Kleeberg, I. Krasnow, M. J. Lefford, E. Mankiewicz, C. McDurmont, G. Meissner, P. Morgan, E. E. Nel, S. R. Pattyn, F. Portaels, P. A. Richards, S. Rüsch, K.-H. Schröder, V. A. Silcox, I. Szabo, M. Tsukamura, and B. Vergmann. 1981. First report of the coop- 
erative, open-ended study of slowly growing mycobacteria by the International Working Group on Mycobacterial Taxonomy. Int. J. Syst. Bacteriol. 31:1-20.

35. Weisburg, W. G., J. G. Tully, D. L. Rose, J. P. Petzel, H. Oyaizu, D. Yang, L. Mandelco, J. Sechrest, T. J. Lawrence, J. Van Etten, J. Maniloff, and C. R. Woese. 1989. A phylogenetic analysis of the mycoplasmas: basis for their classification. J. Bacteriol. 171:6455-6467.
36. Whiley, R. A., H. Y. Fraser, C. W. I. Douglas, J. M. Hardie, A. M. Williams, and M. D. Collins. 1990. Streptococcus parasanguis sp. nov., an atypical viridans Streptococcus from human clinical specimens. FEMS Microbiol. Lett. 68:115-122.

37. Williams, A. M., U. M. Rodriguez, and M. D. Collins. 1991. Intragenetic relationships of enterococci as determined by reverse transcriptase sequencing of small-subunit rRNA. Res. Microbiol. 142:67-74. 